\title{
CHAPTER 11 \\ THE ECONOMIC ASSESSMENT FOR THE RELIABILITY OF INVESTMENT IN THE CONSTRUCTION COMPANY
}

\section{Popova V. V.}

\section{INTRODUCTION}

One of the urgent problems in the activities of construction companies is the problem of accounting when investing of possible negative effects from the adverse effects of the external environment and the associated uncertainty and risk that affect the reliability of the entire investment process. And since the realization of investments by construction companies takes a lot of time and a large number of executors and various resources are involved in it, the likelihood of the impact of negative factors increases significantly compared with other sectors of the economy, causing significant deviations of the real indicators from the planned ones, that is, reduces the reliability of investment.

The problems of the influence of uncertainty on the process of planning, managing, and evaluating the effectiveness of investments, as well as the issues of ensuring and economic assessment for the reliability of investment, were considered by the following scientists: I.V. Bahrova, T.A. Vladymyrova, H.V. Dvas, P. Derevianko, M.A. Zakharevych, V.B. Sirotkin, V.H. Sokolov, Yu.V. Tryfonov, V.H. Fedorenko, T.S. Yarovenko, and others. The problems associated with the peculiarities of the development of construction enterprises were considered by: V.I. Anin, N.I. Verkhoglyadova, V.T. Vecherov, V.V. Herasimov, V.F. Zalunin, Yu.B. Kalugin, V.L. Konashchuk, H.N. Lapin, V.R. Mlodetsky, Yu.V. Orlovska, A.V. Radkevich, V.D. Raizer, Yu.I. Sedykh, V.I. Torkatiuk, R.B. Tian, L.M. Shutenko, and others. A significant contribution to solving the problems of investment activity of enterprises, the strategy of investment development of economic systems, and the risks associated with it were made by: M.V. Hracheva, P.H. Hrabovoy, V.V. Vitlinskyi, S.A. Koshechkin, A.O. Nedosiekin, L.N. Tepman, N.V. Khokhlov, R.A. Fatkhudynov, and others.

However, there are a number of unresolved issues related to the quantitative characteristic of the reliability of the final indicators of 
investment efficiency and taking them into account during the economic justification of the reliability of investment. In most cases, alternative investment options today are incomparable in terms of reliability. In some cases, there is no economic justification for investing at all; in others, the probabilistic nature of environmental parameters is not taken into account. Therefore, the solution to the problem of the economic assessment for the reliability of investment at the construction company based on the system interrelation of reliability of individual indicators is relevant and allows the enterprise to reduce absolute and relative deviations between planned and real indicators of investment efficiency due to timely rejection of investment options that do not correspond to the specified level of reliability.

\subsection{The essence and content of the concept of reliability, features of its accounting in the assessment of investment}

Historically, the emergence of the concept of reliability (as a property of any system) is associated with the widespread use of a systems approach in the 20th century. The theory of systems was first used in exact sciences and in engineering. Accordingly, reliability was considered first exclusively in technical systems. Reliability in technology was defined as the property of the system itself or its elements to perform specified functions while maintaining their performance in specified limits for the required period of time relative to certain conditions and modes ${ }^{1}$.

The application of system theory to the management of organizations in the late 50s was the beginning of numerous studies in the field of reliability not only of production but also of economic systems, based on the calculation of the probability of obtaining the desired value of the efficiency indicator. However, the practice of applying this approach to determining the local reliability of an individual indicator showed that in this case, the real value of the efficiency indicator achieved as a result of the realization of investments often turns out to be much worse than expected.

Given the probabilistic nature of the majority of destabilizing factors, it is quite difficult to establish analytical dependencies that determine the nature and magnitude of their influence on the final

1 Эдельман В. И. Надежность технических систем: экономическая оценка. Москва : Экономика, 1988. 312 c. 
performance indicators, which determines the need for their cumulative accounting using the probabilistic estimates of these indicators.

It is necessary to single out not only "aggregate accounting" but also systemic. Systematicity in this case is manifested in the fact that the conclusion about the reliability of obtaining a final positive economic result should be made not on the basis of individual performance indicators but taking into accounts their systemic (cause-effect) relationship with each other. The legitimacy of such a question is justified by a pattern known by probability theory, the reliability of a single element and a system of such elements are determined differently and may differ significantly depending on the connection pattern of the elements. This is in engineering, and in economic calculations the same tendency is revealed in a somewhat different form. In fact, any indicator of economic efficiency consists of several influencing parameters, each of which is also influenced by the random effects of the external environment, and is considered as a structural element of the system of performance indicator, which is calculated. The systematic nature of these structural elements is determined by a formula that interconnects them in a certain way ${ }^{2}$.

In this way, in economic calculations, it is advisable to investigate and determine the reliability of both a single indicator for each of the quantities included in the calculation, and a complex indicator of reliability determined based on the dependence of individual indicators.

Most of the existing research in this area is focused on assessing the reliability of an enterprise as an economic system, which is determined by diagnosing all levels of an organization's financial and operating activities ${ }^{3}$. Such an approach is acceptable for those enterprises that are at the stage of sustainable development of the life cycle trajectory. In the case when an enterprise develops a strategic development program and plans appropriate investments, the problem arises of determining the integrated reliability of obtaining the expected indicators by which the economic efficiency of the future end result is assessed. Very often, and this is noted in the literature, in analysing the effectiveness of investments, problems arise with the choice of alternative investment

\footnotetext{
Захаревич М.А. Технико-экономическое обоснование надежности инвестирования в интегрированные структуры наукоемких отраслей промышленности: автореф. дис. ... канд. экон. наук: 08.00.05. Санкт-Петербург, 2004. 20 с.

3 Попова В. В. Экономическая надежность параметрических процессов. Економічний простір. 2012. № 58. C. 126-134.
} 
options when comparing their performance indicators, which are known to have different dimensions and therefore cannot be considered as additive. Most often, a compromise subjective decision is made on the basis of providing one of the indicators of high priority (in most cases, this is the net present value NPV) ${ }^{4}$. When reliability is added to the analysis, the process of choosing an option is simplified since the reliability of each indicator can determine its priority in justifying the investment ${ }^{5}$.

An analysis of the definitions of the "reliability of an organization" showed that most of them basically contain the definitions by M. Porter ${ }^{6}$ "the reliability of an organization is defined as the sum of rational distribution and interaction among themselves of technical, technological, personnel, spatial, organizational, informational, financial resources of industrial organizations."

From the point of view of determining a favourable event, the probability of occurrence of which defines the concept of reliability, the above definition makes sense. At the same time, the term "reliability" is a concept of probability theory, as the probability of a favourable event occurring. Based on the above, the considered definition of reliability in terms of probability theory can be written as: enterprise reliability is the probability of an enterprise finding at the reproductive stages of the lifecycle trajectory due to "rational distribution and interaction of technical, technological, personnel, spatial, organizational, informational, financial resources."

Based on the above, it can be noted that there is a certain hierarchy of indicators of reliability, on top of which is an indicator of the reliability of the organization. Each indicator of the upper level is complex in relation to the indicators of the lower level, which are regarded as elementary with respect to it. This shows the dual role of indicators at intermediate levels. In this case, it is logical to assume that the reliability of the lower level indicators should be higher than the final reliability of the upper-level result.

\footnotetext{
${ }^{4}$ Крылов Э. И., Власова В. М., Журавкова И. В. Анализ эффективности инвестиционной и инновационной деятельности предприятия : учеб. пособие. Москва : Финансы и статистика, 2003. 608 c.

5 Здреник В. С. Сутність фінансових інвестицій як об'єкта обліку: проблеми та шляхи їх розв'язання. Украйнська наука: минуле, сучасне, майбутнє. 2014. Ч. 1, вип. 19. С. 51-59.

${ }^{6}$ Портер, М. Международная конкуренция. Конкурентные преимущества стран. Москва : Альпина Паблишер, 2016. 947 с.
} 
Based on this approach, it is possible to define certain types of reliability in the hierarchical system of their relations.

1. Reliability of the company - the definition mentioned above in the text.

2. Reliability of the structural unit - the probability that the results of economic activities of the structural unit will not lead to a decrease in the reliability of the result of the company.

3. Reliability of the system of integrated indicators of financial and operating activities - the probability that the final value of the system of indicators will be at such a level that will provide the necessary reliability of the work of the structural unit.

4. Reliability of the integrated indicator of economic performance the probability that the value of the integrated indicator will be at such a level that will provide the necessary reliability of the system of indicators of financial and operating activities.

5. The reliability of the elementary indicator involved in the calculation of the complex - the probability that the value of the elementary indicator will be at a level that will provide the necessary reliability of the integrated indicator of the economic result of the activity.

For the economic rationale for the reliability of investment, the reliability of the system of complex indicators of economic efficiency is considered: net present value (NPV); internal rate of return (IRR); return on investment $(\mathrm{RI})$; payoff period $(\mathrm{PP})^{7}$.

Complex, in this case, is because it is determined using the elementary indicators included in the calculation formula of each of them. For example, for NPV:

$$
N P V=\sum_{k=1}^{n} \frac{I_{K}}{(1+r)^{K}}+\sum_{j=1}^{m} \frac{C F_{j}^{(+)}}{(1+i)^{j}}
$$

Elementary indicators are:

$I_{K}$ - investment costs in the k-period of time;

$r$ - the discount rate for the investment stage;

$C F_{j}^{(+)}$- positive cash flow in the j-period of time;

$i$ - the discount rate for the commercial phase.

7 Орловська Ю. В., Квактун О. О. Стратегічне управління екологічними інвестиціями: регіональний аспект. Дніпропетровськ, 2011. 280 с. 
This example shows the legitimacy of building a hierarchy of a system of economic reliability from an elementary indicator into a complex system and an enterprise as a whole.

These data indicate the need for further research in the field of economic feasibility of investment reliability.

Economic calculations can be divided into two groups: in the first, they are performed based on deterministic data, and in the second, they are made up of probability values. Calculations for the first and second groups are acceptable and reasonable for certain areas of analysis of economic processes. For example, when analysing the indicators of production and economic activity for the previous period, when the process that forms the indicators has already been completed, the results are deterministic. This also applies to balance settlement. At the same time, when comparable data from a number of past periods are analysed (for example, extrapolation methods are used) in order to determine the patterns of their change, a probabilistic component appears due to random deviations of the considered indicator in each time period.

In general, it can be noted that when an analysis of past periods of an enterprise's economic activity is carried out, the share of calculations performed on a deterministic basis is quite large. Parameters characterizing probabilistic processes (mathematical expectation, variance, etc.) appear in this group of calculations when they analyse the sample of data and try to establish their own pattern of change.

At the same time, a group of economic calculations is carried out to ensure the management process. Management is always focused on the future - operational, current, strategic. In accordance with this, the time period for performing the economic analysis is also determined, the purpose of which is to determine quantitative indicators characterizing the state of the control object for a specific time perspective ${ }^{8}$. These types of calculations are based on an analysis of past realizations of the parameters that influence and forecast the development of the economic process for the future. As noted earlier, the parameters calculated on the basis of statistical processing of past implementations of the process are probabilistic.

A forecast of future processes, like any forecast, is subject to the influence of uncertainty, and the longer the forecast process, the greater

\footnotetext{
${ }^{8}$ Бахмут О. Управління організацією через прогнозування. Економіка. Фінанси. Право. 2000. № 1. C. $10-15$.
} 
the impact of uncertainty and the lower the reliability of such forecast and, accordingly, the calculation based on it, describes the promising trends in the development of this process.

On such regularity development forecast process, the number of researchers paid attention: F. Baikhelt, V. Druzhynin, V.F. Zalunin, V.R. Mlotsetskyi ${ }^{9}$. It is noted that the resulting state of the system can be represented as a "fan" of increasing uncertainty. Moreover, in a stable economic situation, deviations from the mathematical expectation are equally probable in any direction (typical of the symmetric distribution of the probability density of a random variable). In the conditions of unstable economic processes, the range of distribution increases towards negative (undesirable) parameter values, are calculated (the law becomes asymmetric, the mode is shifted to the zone of negative values) (Fig. 1).

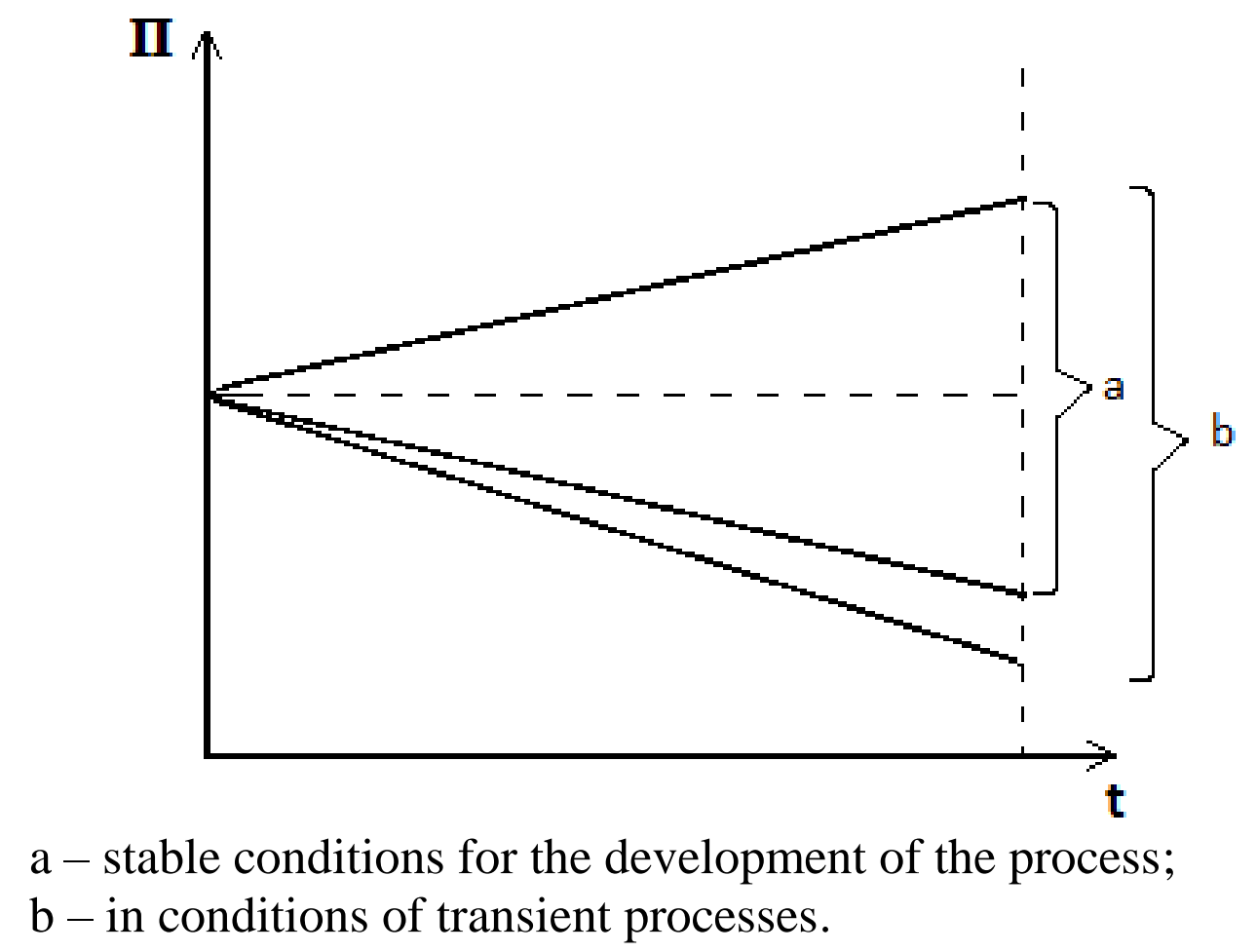

Fig. 1. Dynamics of increasing uncertainty with increasing time of the forecast period

Based on this view of the future development of the economic process, it is concluded that the use of standard, deterministic indicators is acceptable at the stage of developing common goals, but at the stages

\footnotetext{
9 Млодецкий В. Р. Управленческая реализуемость строительных проектов. Дніпропетровськ : Наука і освіта, 2005. 261 с.
} 
of goal realization, the forecast analysis should be based on the uncertainty factor and take into account possible deviations from the forecast development scenario controlled process.

The mismatch of the parametric process in time is of an increasing nature, with the assumption of a normal law of distribution of deviations from the predicted level, to have the following values of the forecast interval.

For a confidence level of $99 \%$, the well-known "three sigma" formula takes the form ${ }^{10}$ :

$$
Q_{n p}^{99 \%} f(t)=Q(t) \pm 3 \delta \cdot \mu(t)
$$

where $\mu(t)$ - is a function depending on the forecast period:

$$
\mu(t)=\sqrt{1+\frac{\left(2 t+t_{0}-1\right)^{2}}{t_{0}^{2}-1}}
$$

where $t-$ is a forecast time;

$t_{0}$ - the so-termed dynamic range in the "retrospective".

This feature in the development of plans was noted long ago and it was taken into account when developing organizational and technological models such as a linear graph, cyclograms, and network graphs. All these and further studies were designed to develop: planning methods, performance evaluation, and management, which together ensured not only the effect of uncertainty on the process itself but also higher reliability of achieving the final result.

Analysis of the current state of the theory and practice of planning investment processes showed a lack of reliability and authenticity of these plans and programs. So the actual cost and duration of construction significantly 1.5-2 times higher than the corresponding figures at the planning stage $\mathrm{e}^{11}$.

In the early $90 \mathrm{~s}$ of the last century, Professor A.A. Husakov formulated the concept of organizational and technological reliability (OTR) in the construction industry" "The organizational and technological reliability of the construction industry is the ability of the

\footnotetext{
${ }^{10}$ Семенов В. А. Теория вероятностей и математическая статистика : Учебное пособие. Стандарт третьего поколения. Санкт-Петербург : Питер, 2013. 192 с.

11 Конащук В. Л. Аналіз економічних можливостей підрядного підприємства 3 реалізації інвестиційного проекту. Научно-технический сборник ХНАГХ. 2010. № 94. С. 44-50.

12 Гусаков А. А., Гинзбург А. В. Веременко С. А. Организационно-технологическая надежность строительства. Москва : Стройиздат. 1994. 470 с.
} 
construction organization to maintain the operating parameters within the specified limits and obtain the planned result under the given production conditions".

Also in this work, attention is drawn to the fact that the term "reliability" should be applied only to the result of the system's activity, and not to individual factors affecting the result. Therefore, it is necessary to clearly formulate what is the result and give a quantitative assessment of the indicators characterizing the effectiveness of achieving this result.

According to the reliability criterion, evaluations of the results of the implementation of large programs over the past few decades have been carried out. So, the work of Professor A.A. Gusakov presents a table for determining the reliability of the main parameters by stages of the investment process (Table 1).

Table 1

Acceptability (reliability) of the values of the main parameters in the economic and organizational-technological documents on the stages of the investment process of building industrial complexes (fragment)

\begin{tabular}{|l|c|c|c|c|c|}
\hline \multirow{2}{*}{$\begin{array}{l}\text { The main parameters } \\
\text { of construction }\end{array}$} & \multicolumn{4}{|c|}{$\begin{array}{l}\text { Index of deviation of values (average } \\
\text { values) of parameters in documents }\end{array}$} \\
\cline { 2 - 6 } & TEA & CMP & OMP & AMP & AR \\
\hline Resource consumption & 1 & 1,25 & 1,3 & 1,35 & 1,42 \\
\hline $\begin{array}{l}\text { The interaction of factors of } \\
\text { production (models, graphics) }\end{array}$ & 1 & 0,75 & 0,6 & 0,3 & 0,2 \\
\hline $\begin{array}{l}\text { Development of factors } \\
\text { of production (duration } \\
\text { of cycles, etc.) }\end{array}$ & 1 & 0,82 & 0,7 & 0,5 & 0,3 \\
\hline$\ldots \ldots \ldots \ldots \ldots \ldots \ldots \ldots \ldots \ldots \ldots$ & & & & & \\
\hline Total construction system & 1 & 0,8 & 0,55 & 0,5 & $0,42-0,11$ \\
\hline
\end{tabular}

where TEA - technical and economic assessment;

CMP - construction management plan;

OMP - operations management plan;

AMP - activities management plan;

AR - actual result.

It can be seen from the above table that the reliability of the decisions made during the feasibility studies for the construction of industrial complexes is very low and reaches only $11-42 \%$. 
Thus, even today, the problem of the reliability of plans and programs, designated several decades ago, remains relevant, the solution of which is seen in the "distant future".

If we consider in more detail the term of organizational and technological reliability, then in the considered sources it is determined and evaluated as the probability of achieving the planned targets.

Obviously, since plans are being developed in the current period of time, and are being implemented in the future, this situation objectively already introduces a disagreement that increases with the time between forecasts and realities arising from the implementation of these plans. However, if you pay attention not to the plans but to the quantitative indicators characterizing the development of production processes, organizationally and technologically interrelated in time and space, you can see that their calculation, and therefore, the result are not accurate and contain certain errors.

These errors (inaccuracies) are formed by the adopted model of the display of the plan (line graph, cyclogram, network graph) and the structure of the formulas for calculating the parameters of this plan.

In the work, A.L. Yaremenko summarizes the characteristics of models that are classified according to the method of describing an object (Table 2), which contains recommended areas of their application and a preliminary assessment of the accuracy of the results obtained on their basis ${ }^{13}$.

In construction, when developing plans, organizational and technological models are often used on the basis of a linear schedule (Gantt chart), a cyclogram or a network schedule. As can be seen from the table, they provide relative accuracy in the range of $75-80 \%$. However, the accuracy of the forecast is determined not so much by a graph as by parameters characterizing quantitative values describing the purpose of planning. When calculating these parameters, a series of calculations are performed on the original data. This calculation algorithm includes several elementary functions. For each elementary function, using the analysis of variance, the error is calculated based on the errors of the argument parameters ${ }^{14}$.

\footnotetext{
${ }^{13}$ Яременко О. Л., Сумец А. М. Операционный менеджмент. Харьков : Фолио, 2002. 231 с.

14 Болотин С. А. Основы постановки частной задачи комбинаторной оптимизации строительства комплексных объектов. Известия вузов. Строительство. 2010. №4. С. 32-35.
} 
Table 2

Characteristic features of mathematical models

\begin{tabular}{|l|l|c|}
\hline \multicolumn{1}{|c|}{ Models } & \multicolumn{1}{c|}{ Primary applications } & $\begin{array}{c}\text { Relative } \\
\text { calculation } \\
\text { accuracy }\end{array}$ \\
\hline Algebraic & $\begin{array}{l}\text { Common operational problems: } \\
\text { analysis of process costs } \rightarrow \\
\text { profit, etc. }\end{array}$ & $90-95 \%$ \\
\hline $\begin{array}{l}\text { Line charts, } \\
\text { cyclograms }\end{array}$ & $\begin{array}{l}\text { Production planning, } \\
\text { distribution of labour }\end{array}$ & $75-80 \%$ \\
\hline Network & $\begin{array}{l}\text { Research and design work, } \\
\text { development of production } \\
\text { projects }\end{array}$ & up to 75\% \\
\hline Probably statistical & $\begin{array}{l}\text { Evaluation of service systems } \\
\text { - queuing theory } \\
\text { models; }\end{array}$ & up to 80\% \\
\hline - inventory models; & $\begin{array}{l}\text { Asset management firms, } \\
\text { enterprises }\end{array}$ & $70-75 \%$ \\
\hline - statistical; & $\begin{array}{l}\text { In various areas with a fair } \\
\text { amount of uncertainty }\end{array}$ & up to 70\% \\
\hline $\begin{array}{l}\text { Regression- } \\
\text { correlation }\end{array}$ & $\begin{array}{l}\text { In the areas of production } \\
\text { management }\end{array}$ & $85-95 \%$ \\
\hline
\end{tabular}

Thus, the calculation of economic indicators itself contains uncertainty, which is also caused by the choice of the type of model and the scheme for calculating this indicator.

In accordance with this, the remark made by Professor A.A. Husakov in the 70s-90s of the last century: "For a proper assessment of the reliability of the designed solutions, reliable assessment methods are needed. However, the problem of "reliability of the economy" has until recently been overlooked not only by institutions but also by individual authors, whereas the solution to the general problem of efficiency and reliability must begin with increasing the reliability of economic assessment methods when choosing design solutions." 


\subsection{Methodical prerequisites for the economic rationale for the reliability of investment}

Reliability is one of the main characteristics of the quality of functioning of technical, organizational, technological, production, and economic systems.

Reliability is usually understood as the probability that at any time the system under investigation will be in working condition. In these works, it is noted that, unlike technical systems, which are characterized by instantaneous failures, there is a parametric failure in organizational and economic systems when the system remains operational but the parameters characterizing its efficiency are below the permissible level and due to the mobilization of additional resources seeks to return controlled parameters to the specified efficiency limits.

It is obvious that the reliability of the system depends, on the one hand, on its internal properties, and on the other hand, on various external influences that are random in nature.

If the system has a sufficient level of resources to compensate for negative random external influences, then it also has a high level of reliability. However, the availability of additional resources is associated with additional costs. On the other hand, the lack of reliability of the system leads to frequent parametric failures, an increase in the total time of the recovery period, resulting in a decrease in the average for the period of the system performance indicator ${ }^{15}$.

Thus, the problem of reliability is closely related to the problem of the economic efficiency of the functioning of the organizationaleconomic system. In this formulation, the solution is reduced to the classical optimization problem.

Such an approach will allow approaching the solution to the problem of a rational level of reliability. In the existing literary sources, this level is determined in the range of $0,4-0,75$, but without deep justification for why it is in this range.

The expansion of the economic parameters included in the solution of the problem, together with the probabilistic ones, will make it possible to solve this problem when choosing an economically sound level for these conditions. Therefore, obviously, it is impossible to talk

\footnotetext{
15 Млодецький В. Р., Тян Р. Б., Ткаченко В. А. Аспекти управління інноваціями проектноорієнтованих організацій: монографія. Дніпро : ДУ ім. А. Нобеля; вид-во «Монолит», 2012. 242 с
} 
about a rational value of reliability for all possible options since in each case there is an economically reasonable level of reliability.

In a number of works, the interrelation of the concepts of reliability and efficiency is noted - the higher the reliability of the system, the higher its performance indicators, but this trend can be traced to a certain level. In the work by O.L. Yaremenko, a qualitative dependence of efficiency on reliability is given (Fig. 2) ${ }^{16}$.

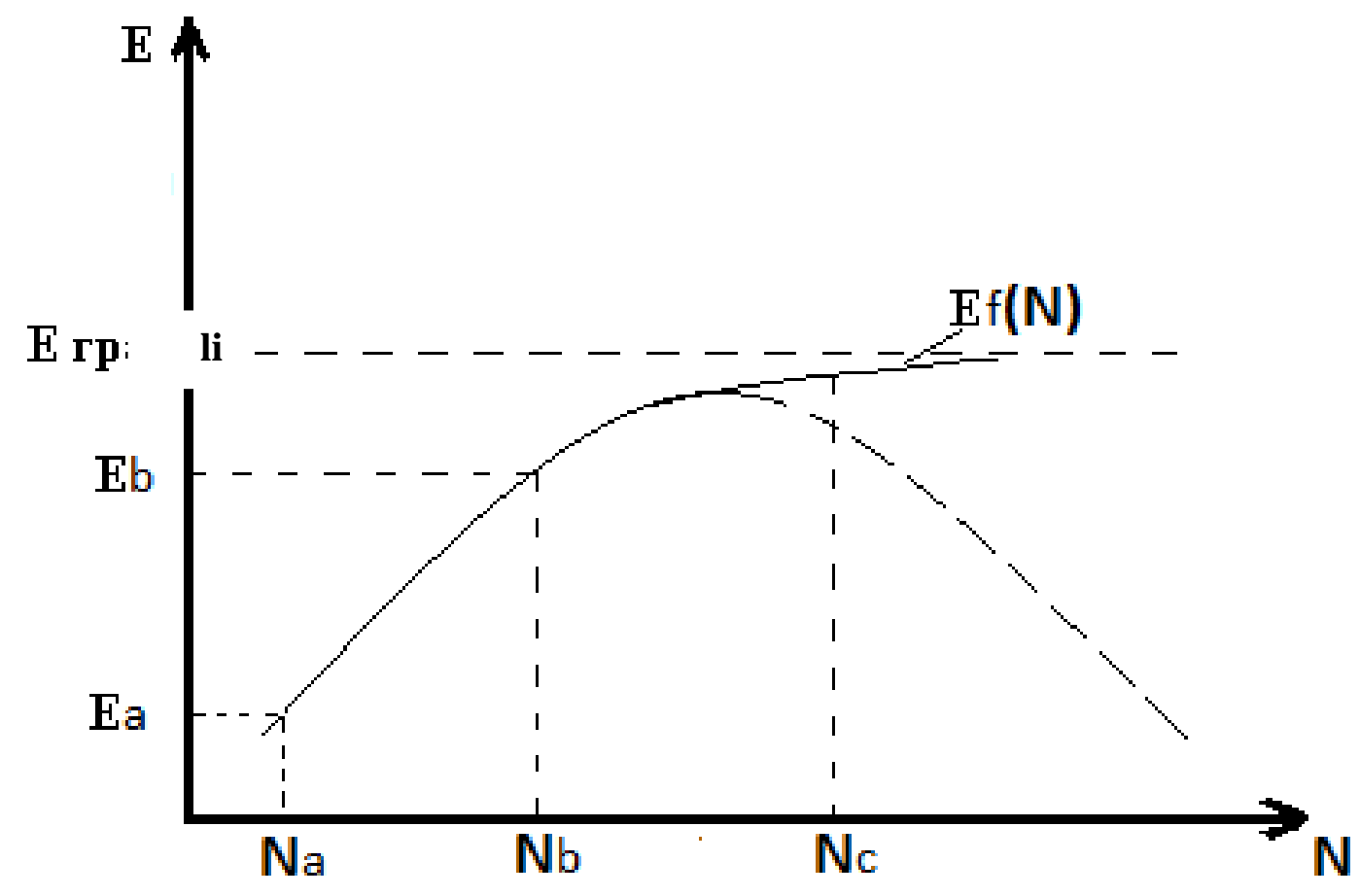

E lim - limiting efficiency;

$\mathrm{Ef}(\mathrm{N})$ - the trajectory of the dependence of efficiency on reliability.

\section{Fig. 2. The dependence of efficiency $(E)$ on reliability $(N)$}

Dependency analysis allows identifying the following characteristic areas:

1. $(a-b)$ - the trajectory is approximated by a straight line with a high value of the angular coefficient and in this area, the change in reliability significantly affects the efficiency;

2. $(b-c)$ - transition section, within which the influence of reliability on efficiency decreases in progression - a small increase in efficiency corresponds to a significant increase in reliability;

${ }^{16}$ Яременко О. Л. Операционный менеджмент. Харьков : Фолио, 2002. 231 с. 
3. Zone >c, where the function asymptotically approaches some marginal efficiency characteristic of this system.

An increase in reliability must be accompanied by an increase in efficiency, and these parameters correlate directly in proportion to each other only up to a certain point (Fig. 1.5, trajectory $a-b$ ). Thus, for practical purposes, this particular trajectory segment may be of interest.

Uncertainty is an unavoidable quality of the market environment, due to the fact that a large number of factors of different nature and direction have their simultaneous effect on market processes. For construction companies, the problem of uncertainty is of particular relevance - this is due to the long period of the building of the construction facility and, thus, the indicators of economic efficiency, which participants of the investment process expected can be outside of the tolerance level. In the conditions of the economic crisis, management decisions began to be taken with a greater share of risk. The reason for this risk is the lack of information and continuously increasing prices of factors of production.

In calculations that take into account the probabilistic nature of real processes, as a rule, use the following concepts:

$-\operatorname{risk}(R)$

- reliability $(N)$;

- uncertainty;

- authenticity.

Risk and reliability are events that complement each other to complete, so from a mathematical point of view, it does not matter which of these categories to choose as the object of study $(N+R=1)$. In their works, I.V. Bagrova and T.S. Yarovenko conducted a detailed analysis of the definition of the concept of "risk" from the standpoint of different points of view. Attention is paid to risk accounting as the main factor ensuring the reliability of investment ${ }^{17}$.

By definition of V.V. Kovalev, the risk describes the likelihood of financial loss, expressed ${ }^{18}$ :

a) in the possibility of not achieving the goal;

b) in the uncertainty of the predicted result;

c) in the subjectivity of the assessment of the predicted result.

\footnotetext{
17 Багрова I. В., Яровенко Т. С. Основні аспекти визначення ризику в забезпеченні надійності інвестиційних проектів. Науковий вісник НГУ. 2010. № 4. С. 129-133.

${ }^{18}$ Ковалев В. В. Курс финансового менеджмента: учебник. Москва : Проспект, 2011. 480 с.
} 
The main property of risk - it takes place only in relation to the future and is inextricably linked with forecasting and planning.

Risk and reliability are measures of the probability of a certain event, the state of which is uniquely uncertain and is characterized by a certain level of uncertainty. The dictionary meaning of "uncertainty" is "an indefinite mathematical expression that allows for many solutions" $" 19$.

From the position of probability theory, uncertainty is determined by the possible complete list of states of the monitored parameter. The condition "full list" means that with a probability equal to one we can assert that the parameter is within the possible state and the probability of going beyond these limits tends to zero.

In a number of papers ${ }^{20}$, uncertainty is characterized as an objective state of nature, and risk as a kind of "derivative of a state of uncertainty, which describes the possibility of an undesirable event" ${ }^{21}$. The risk appears when any possible value of the parameter is chosen in the indicated range. The selection process is subjective, therefore, it is noted that the risk category is subjective as opposed to uncertainty.

Thus, uncertainty is a risk measurement environment and can be defined:

- in the form of probability distributions: the distribution of a random variable is precisely known, but it is not known what specific value the random variable will acquire;

- in the form of subjective probabilities: the distribution of tasks in the form of the probability of occurrence of individual values determined by the expert;

- in the form of an uncertainty interval: the distribution of a random variable is unknown, but it is known that it can take any value in a certain interval.

The impact of the level of uncertainty directly determines the level of risk.

The level of uncertainty is influenced by factors of both the internal and external environment. Factors of the internal environment must be considered at the stage of investment realization, and at the stage of

\footnotetext{
19 Толковый словарь русского языка. Том І. Под редакцией Д.Н. Ушакова. Москва : ООО «Издательство Астрель», ООО «Издательство АСТ», 2000.848 с.

${ }^{20}$ Кошечкин С.A. Концепция риска инвестиционного проекта. Корпоративный менеджмент. URL: http://www.cfin.ru/finanalysis/koshechkin.shtml

21 Савчук В. П. Управление финансами: Интернет портал для управленцев. URL: http://www.management.com.ua/finance/finlll.html.
} 
planning and economic justification of investments, environmental factors are mainly taken into account. These features must be taken into account when developing forecasts regarding the formation of cash flow parameters, which are the basis for calculating investment performance indicators, the values of which make the final decision on the advisability of investing. It is obvious that the reliability of forecasts decreases with an increase in the forecast period and, with an increase in the complexity of unstable external conditions this period shortens more intensively and may in some cases reach $1-2$ years.

Obviously, no matter how the state of uncertainty is formalized, we have a discrete spectrum of possible states of the monitored parameter in the possible range of its values and the probability that this parameter falls into the boundaries of each range.

In the work $^{22}$, attention was paid to the factors implemented in construction investment. The following of them are distinguished: technical, organizational, resource (material, financial), economic. Each of the selected factors is characterized by its "input" list of parameters that are "input" for evaluating other factors. So, the parameters of technical feasibility are input for organizational and so on. As a result, the researcher is interested in the level of final feasibility, and its conditional decomposition into separate factors is the methodology of researching the whole through its components, taking into account their interdependence and mutual influence.

Each of these factors is the subject of independent research. In further work, economic feasibility is chosen as research. By definition, "feasibility" is the ability to achieve a goal with a limited amount of resources available for a certain period of time. The concept of "opportunity" has a strict mathematical analogy - probability, that is, "reliability."

As noted in $^{23}$, the term "reliability" should be applied only to the result, and not to individual factors affecting the result. If reliability is investigated as an economic category, then in the future as the object of this reliability we will consider investments.

It is necessary to determine what should be considered as a result of the investment. Here we can distinguish two components if we talk

\footnotetext{
22 Тян Р. Б., Павлов І. Д., Головкова Л. С. Управління проектами у виробничих системах. Запоріжжя : ГУ «ЗІДМУ», 2006. 208 с.

${ }^{23}$ Гусаков А. А., Гинзбург А. В., Веременко С. А. Организационно-технологическая надежность строительства. Москва : Стройиздат. 1994. 470 с.
} 
about investing in construction. The first component of the material is the object itself. A theory of organizational and technological reliability has been developed that is precisely concerned with the investigation of the reliability of related processes: technical, technological, and organizational. The second component is the economic processes that throughout the implementation of investments (duration of the life cycle) form its effectiveness.

In the literature on the economic analysis of investments, the following ratios between standard indicators for evaluating the effectiveness of investment are provided (Table 3).

Table 3

Conditions for decision for practicability to invest

\begin{tabular}{|c|c|c|c|}
\hline \multicolumn{3}{|c|}{ Performance indicators } & \multirow{2}{*}{ Alternate solution } \\
\cline { 1 - 2 } NPV & IRR & RI & Positive decision \\
\hline$>0$ & $>\mathrm{CC}^{*}$ & $>1$ & Negative decision \\
\hline$<0$ & $<\mathrm{CC}$ & $<1$ & State of limit equilibrium \\
\hline$=0$ & $=\mathrm{CC}$ & $=1$ & \\
\hline
\end{tabular}

$* \mathrm{CC}-$ the cost of capital, which is advanced in investment activities.

Unlike technical, technological, and organizational processes, where most often reliability is the object of study, risk parameter is more often studied in economic literature. As noted earlier, there is no fundamental difference in choosing risk or reliability, since they complement each other before the full event.

Here is the definition of economic risk ${ }^{24}$ :

1. Economic risk - the possibility of incurring losses due to the random nature of the results of economic decisions that are taken or in the implementation of certain actions.

2 . In the investment sphere, economic risk represents the probability of incurring losses as a result of unsuccessful capital investment.

3. Economic risk in business is the risk that the products produced as a result of business activities cannot be sold at a price that covers operating and maintenance costs.

The above definitions consider economic risk as a fact of a negative event (system failure). The existing definitions of technical and organizational reliability focus on the property (ability) of the system to

${ }^{24}$ Борисов А. Б. Большой экономический словарь. Москва : Книжный мир, 2003. 895 с. 
maintain an operational condition for a certain length of time. Based on this, we give a definition of investment reliability.

The reliability of investment is the result of a systemic influence on the processes that occur in the control object and are aimed at ensuring that the values of economic efficiency indicators are obtained from the results of the investment process not lower than the established probability level.

Here, under the "systemic action" understood all possible factors influencing the controlled process, these are technical, organizational, technological, financial, and others, and economic indicators act as a criterion for evaluating the effectiveness of such an action.

Thus, based on the analysis of literary sources, the dependence of the level of reliability on the degree of uncertainty of the external environment, which is the cause of the risk, is substantiated. Therefore, the level of reliability is a subjective category, which is determined by the investor's desire to obtain a certain level of income at an acceptable level of risk for implementing an investment decision.

Based on this, the possible future risks of non-receipt or shortfall in the expected income level, which can reflect a more objective picture of the investment process, should be included in the calculation of investment performance.

\section{CONCLUSION}

As a result of the analysis of literary sources in the field of justifying the reliability of investment in the construction industry, it was established that the existing methods are fragmented, non-systemic in nature, and do not take into account probabilistic processes affecting the operation of the economic system.

Joint consideration of the definitions of organizational and technological reliability, focuses on the properties of the system to maintain an operating condition for a certain period of time, and economic risk, as a fact of a negative event, allow formulating the concept of reliability of investment.

Analysis of the probabilistic nature of real economic processes showed that the uncertainty of the state of the system is an objective value, and reliability is subjective, associated with the choice of the desired level of confidence in obtaining a positive result.

It is established that the reliability decreases more intensively with time than the higher the intensity of the increase in system uncertainty, 
which is important when determining the duration of forecasting the development of the investment process and calculating economic efficiency indicators.

It is established that the duration of investment affects the accuracy of the forecast, and therefore, the reliability of the final result, which emphasizes the importance of determining the payback period of investments.

\section{SUMMARY}

The transformation processes in the national economy have significantly changed the economic, legal, and social environment of the construction industry. Now the further development of the construction industry requires the attraction of significant investment resources, and this especially applies to business entities that are direct participants in investment processes. Since the realization of investments by construction companies takes a lot of time and a large number of executors and various resources are involved in them, the investment process at the enterprises of the construction industry requires a systematic approach to its management.

The article reveals the problem of the influence of uncertainty in conditions of incomplete information and solves the problem of increasing the reliability of the final result and the efficiency of the investment process.

\section{REFERENCES}

1. Эдельман В. И. Надежность технических систем: экономическая оценка. Москва : Экономика, 1988. 312 с.

2. Захаревич М. А. Технико-экономическое обоснование надежности инвестирования в интегрированные структуры наукоемких отраслей промышленности: автореф. дис. ... канд. экон. наук: 08.00.05. Санкт-Петербург, 2004. 20 с.

3. Попова В. В. Экономическая надежность параметрических процессов. Економічний простір. 2012. № 58. С. 126-134.

4. Крылов Э. И., Власова В. М., Журавкова И. В. Анализ эффективности инвестиционной и инновационной деятельности предприятия : учеб. пособие. Москва : Финансы и статистика, 2003. 608 c. 
5. Здреник В. С. Сутність фінансових інвестицій як об'єкта обліку: проблеми та шляхи їх розв'язання. Украӥнська наука: минуле, сучасне, майбутнє. 2014. Ч. 1, вип. 19. С. 51-59.

6. Портер М. Международная конкуренция. Конкурентные преимущества стран. Москва : Альпина Паблишер, 2016. 947 с.

7. Орловська Ю. В., Квактун О. О. Стратегічне управління екологічними інвестиціями: регіональний аспект. Дніпропетровськ, 2011. $280 \mathrm{c}$.

8. Бахмут О. Управління організацією через прогнозування. Економіка. Фінанси. Право. 2000. № 1. С. 10-15.

9. Млодецкий В. Р. Управленческая реализуемость строительных проектов. Днепропетровск : Наука і освіта, 2005. 261 с.

10. Семенов В. А. Теория вероятностей и математическая статистика: Учебное пособие. Стандарт третьего поколения. СанктПетербург : Питер, 2013. 192 с.

11. Конащук В. Л. Аналіз економічних можливостей підрядного підприємства 3 реалізації інвестиційного проекту. Научно-технический сборник ХНАГХ. 2010. № 94. С. 44-50.

12. Гусаков А. А., Гинзбург А. В. Веременко С. А. Организационно-технологическая надежность строительства. Москва : Стройиздат, 1994. 470 с.

13. Яременко О. Л., Сумец А. М. Операционный менеджмент. Харьков : Фолио, 2002. $231 \mathrm{c.}$

14. Болотин С. А. Основы постановки частной задачи комбинаторной оптимизации строительства комплексных объектов. Известия вузов. Строительство. 2010. № 4. С. 32-35.

15. Млодецький В. Р., Тян Р. Б., Ткаченко В. А. Аспекти управління інноваціями проектно-оріснтованих організацій : монографія. Дніпро : ДУ ім. А. Нобеля; Вид-во «Монолит», 2012. 242 c.

16. Яременко О. Л. Операционный менеджмент. Харьков : Фолио, 2002. $231 \mathrm{c.}$

17. Багрова I. В., Яровенко Т. С. Основні аспекти визначення ризику в забезпеченні надійності інвестиційних проектів. Науковий вісник НГУ. 2010. № 4. С. 129-133.

18. Ковалев В. В. Курс финансового менеджмента : учебник. Москва : Проспект, 2011. 480 с. 
19. Толковый словарь русского языка. Том I. Под редакцией Д. Н. Ушакова. Москва : ООО «Издательство Астрель», ООО «Издательство АСТ», 2000. 848 с.

20. Кошечкин С. А. Концепция риска инвестиционного проекта. Корпоративный менеджмент. URL: http://www.cfin.ru/ finanalysis/koshechkin.shtml

21. Савчук В. П. Управление финансами: Интернет портал для управленцев. URL: http://www.management.com.ua/finance/finlll.html

22. Тян Р. Б., Павлов І. Д., Головкова Л. С. Управління проектами у виробничих системах. Запоріжжя : ГУ «ЗІДМУ», 2006. $208 \mathrm{c}$.

23. Гусаков А. А., Гинзбург А. В., Веременко С. А. Организационно-технологическая надежность строительства. Москва : Стройиздат. 1994. $470 \mathrm{c.}$

24. Борисов А. Б. Большой экономический словарь. Москва : Книжный мир, 2003. 895 с.

\section{Information about the author:}

Popova V. V.

Candidate of Economic Sciences, Associate Professor at Department of Accounting, Economics und Human Resources Management, Prydniprovska State Academy of Civil Engineering and Architecture, Ukraine 